\title{
SHOULD INDONESIA ACCEDE TO THE 1951 REFUGEE CONVENTION AND ITS 1967 PROTOCOL?
}

\author{
Dita Liliansa and Anbar Jayadi*
}

\begin{abstract}
*Authors are Assistant Lecturers of International Law at the Faculty of Law Universitas Indonesia and Researchers at the Center for International Law Study. Both authors obtained their Bachelor of Law (Sarjana Hukum) from the Faculty of Law Universitas Indonesia. This article is produced through a research funded by the Manager of Research and Community Services, Faculty of Law Universitas Indonesia in 2015.
\end{abstract}

\section{Article Info}

Received : 12 August 2015 | Received in revised form : 14 December 2015 | Accepted : 21 December 2015 Corresponding author's e-mail : dita.liliansa@gmail.com / anbar.jayadi@gmail.com

\begin{abstract}
Being a non-party to the 1951 Convention relating to the Status of Refugees ("1951 Refugee Convention") and 1967 Protocol relating to the Status of Refugees ("1967 Protocol"), Indonesia does not have legal obligations to provide permanent resettlement for asylum seeker and/or refugee. However, as a transit country for those seeking shelter in Australia, Indonesia undergoes a myriad of issues resulting from illegal entrance by asylum seeker and/or refugee. Besides having neither legal framework nor domestic mechanism to handle asylum seekers and/or refugee, Indonesia's immigration law identifies every foreigner including asylum seeker and refugee who unlawfully enter Indonesia's territory into the same box as illegal migrant. It then leads to the arrest of asylum seeker and/or refugee to be put in an over-capacity detention center or other places. This paper will analyze various issues related to asylum seeker and refugee in Indonesia and to weigh whether it is indispensable for Indonesia to accede to the 1951 Refugee Convention and its 1967 Protocol.
\end{abstract}

Keywords: refugee, asylum seeker, transit country, Indonesia.

\begin{abstract}
Abstrak
Sebagai negara yang tidak menjadi peserta dari Convention relating to the Status of Refugees ("Konvensi Pengungsi") dan Protokolnya, Indonesia tidak memiliki kewajiban hukum untuk menyediakan penempatan permanen bagi pencari suaka dan/atau pengungsi. Namun demikian, sebagai negara transit bagi mereka yang mencari suaka ke Australia, Indonesia menghadapi berbagai permasalahan akibat illegal entrance yang dilakukan oleh pencari suaka dan/atau pengungsi. Di samping Indonesia tidak memiliki kerangka hukum ataupun mekanisme untuk mengatasi pencari suaka dan/atau pengungsi, hukum imigrasi Indonesia mengkategorikan setiap orang asing termasuk pencari suaka dan pengungsi yang masuk ke wilayah Indonesia dengan melawan hukum sebagai migran illegal. Hal ini mengakibatkan penahanan pencari suaka dan/atau pengungsi yang kemudian ditempatkan di rumah detensi atau tempat lain yang sudah melebihi kapasitas jumlah orang. Tulisan ini mengkaji pelbagai permasalahan pencari suaka dan pengungsi di Indonesia serta menilai ada atau tidaknya urgensi bagi Indonesia untuk melakukan aksesi atas Konvensi Pengungsi dan protokolnya.
\end{abstract}

Kata Kunci: pengungsi, pencari suaka, negara transit, Indonesia. 


\section{Introduction}

Geographically, Indonesia has an intermediate point between Middle East and Asia as the countries of origin of asylum seeker and refugee on the one hand, and Australia as resettlement country. It then places Indonesia at a difficult position as a transit country which is constantly exposed to the impact of "irregular migrants" which mostly comes from Myanmar. ${ }^{1}$ According to the United Nations ("UN"), the number of Rohingya asylum seekers coming to Indonesia has increased from 30 people in 2010 to 360 people in $2015 .^{2}$

Despite the high volume of refugees entering its territory for transit, Indonesia has not yet acceded to the 1951 Convention relating to the Status of Refugees ("1951 Refugee Convention") and the 1967 Protocol relating to the Status of Refugees ("1967 Protocol") thus Indonesian Government does not have the legal obligations to take an active role in deciding the status of Rohingya refugees or asylum seekers. ${ }^{3}$ This leads to a dilemma for both asylum seekers and refugees who are intentionally or unintentionally stranded in Indonesia, and the Indonesian Government itself.

Having no domestic mechanism governing asylum seekers and refugees, Indonesia categorizes asylum seeker and refugee who enter Indonesian territory without prior authorization into one box as "illegal migrant". In the context of asylum seeker and refugee, the main legal instrument that is applied in Indonesia is the Law No. 6 of 2011 on Immigration ("Law 6/2011") which can be explained in the table below:

Table 1: Law 6/2011 related to Asylum Seekers and Refugees

\begin{tabular}{|c|c|c|c|}
\hline No & Matters & Provision & Remark \\
\hline 1 & Foreigner & Article 1 number 9 & A person who is not national of Indonesia. \\
\hline 2 & Deterrence & $\begin{array}{l}\text { Article } 1 \text { number } \\
29\end{array}$ & $\begin{array}{l}\text { Prohibition for foreigner to enter Indonesia's territory } \\
\text { according to immigration reasons. }\end{array}$ \\
\hline 3 & $\begin{array}{l}\text { Administrative } \\
\text { action }\end{array}$ & $\begin{array}{l}\text { Article } 1 \text { number } \\
31\end{array}$ & $\begin{array}{l}\text { Administrative sanction set out by immigration officer for } \\
\text { foreigner outside of court. }\end{array}$ \\
\hline 4 & $\begin{array}{l}\text { People } \\
\text { smuggling }\end{array}$ & $\begin{array}{l}\text { Article } 1 \text { number } \\
32\end{array}$ & $\begin{array}{l}\text { Actions which aim for profit, either directly or indirectly, for } \\
\text { himself or another person either organized or unorganized, } \\
\text { or instructing others to bring a person or a group of people } \\
\text { either organized or unorganized who do not have any legal } \\
\text { right to enter or exit from Indonesian territory, either by } \\
\text { using legal or false documents, or without travel documents, } \\
\text { either through the immigration check or not. }\end{array}$ \\
\hline 5 & $\begin{array}{l}\text { Immigration } \\
\text { detention center }\end{array}$ & $\begin{array}{l}\text { Article } 1 \text { number } \\
33\end{array}$ & $\begin{array}{l}\text { Technical operational unit who carries out immigration } \\
\text { function as a temporary shelter or foreigner who is subject to } \\
\text { administrative action on immigration. }\end{array}$ \\
\hline
\end{tabular}

${ }^{1}$ UNHCR (1), “UNHCR di Indonesia," http://www.unhcr.or.id/id/unhcr-ambassador-id, accessed 22 April 2015..

2 VOA Indonesia, "Warga Rohingya Hadapi Ketidakpastian di Indonesia," http://www.voaindonesia. com/content/warga-rohingya-hadapi-ketidakpastian-di-indonesia/1695594.html, accessed 19 April 2015.

${ }^{3}$ Hukum Online (1), “Indonesia Perlu Ratifikasi Konvensi Tentang Pengungsi," http://www.hukumonline.com/berita/baca/lt4f351aacc4a70/indonesia-perlu-ratifikasi-konvensi-tentang-pengungsi, accessed 22 April 2015. 
According to the Table 1, it can be concluded that Law 6/2011 does not have explicit clause on asylum seeker and refugee. Asylum seeker and refugee are grouped into foreigner category and most of them do not hold valid travel document thus administrative action applies. Those who receive administrative action will be put into immigration detention center or other places. However, if those asylum seekers and refugees are victims of people smuggling or human trafficking, there is an exception that they will not be charged with immigration action although they will still be placed in a detention center or other places. ${ }^{4}$ Through Directive Directorate General of Immigration in 2010, the rights to get an access to the United Nations High Commissioner for Refugee ("UNHCR") for refugee and asylum seeker who are arrested in Indonesia and placed in a detention center are guaranteed. ${ }^{5}$ Indonesian Government, in this case is the Ministry of Foreign Affairs and the Ministry of Law and Human Rights, has been working hand in hand with UNHCR in building the capacity of government officers who handle refugee and asylum seeker in Indonesia. ${ }^{6}$

Intermingling between refugee and asylum seeker on the one hand and illegal migrant in the same detention center may spark conflict and over-capacity. ${ }^{7}$ One of the examples of conflict raising from over-capacity and tempering between refugees and asylum seekers and illegal migrants has happened in the Detention Center in Medan which caused 8 Rohingyas died. ${ }^{8}$ Over-capacity and people being prone to conflict are one of indications that the right to safety in Detention Center is not optimal. Right to safety in this context is the right to safety as guaranteed in the Law No. 39 of 1999 on Human Rights ("Law 39/1999"). Article 30 of Law 39/1999 stipulates that "Everyone has the right to safety" in which the word "everyone" means protection over the right to safety provided by the Indonesian Government which covers everyone within the Indonesian territory, including Rohingya refugees and asylum seekers. Therefore, this research is pivotal to review various legal actions carried out by the Indonesian Government in the mission to provide protection towards Rohingya refugees and asylum seekers.

\section{Issues of Asylum Seekers and Refugees in Indonesia}

Factors that have contributed to international migration include many things. Among the people on the move today, many are seeking employment or educational opportunities while others want to reunite with family members and still more are fleeing persecution, conflict or violence in their countries. ${ }^{9}$ This migration has increased every year as proven by data released by the United Nations Department

${ }^{4}$ Indonesia (1), Undang-Undang tentang Imigrasi (Law regarding Immigration), UU No. 6 Tahun 2011, LN No. 52 Tahun 2011 (Law Number 6 Year 2011, SG No. 52 Year 2011), arts 86-87.

5 UNHCR (2), “Relasi dengan Pemerintah dan Peningkatan Kapasitas," http://www.unhcr.or.id/id/ tugas-a-kegiatan/relasi-dengan-pemerintah-a-peningkatan-kapasitas, accessed 22 April 2015.

${ }^{6}$ For instance, training on safety and security organized by the Directorate General of Immigration in collaboration with UNHCR on 11-14 March 2014 in a detention house in Tanjung Pinang. ("Pelatihan Keselamatan dan Keamanan di Rudenim Tanjung Pinang," http://www.unhcr.or.id/id/pelatihan-keselamatandan-keamanan-di-rudenim-tanjung-pinang, accessed 22 April 2015).

7 “Beberapa Rumah Detensi Imigrasi Over Kapasitas," http://jakarta.kemenkumham.go.id/berita-hukum-dan-ham/671-beberapa-rumah-detensi-imigrasi-over-kapasitas-, accessed 22 April 2015.

${ }^{8}$ Okezone, "Delapan Pengungsi Rohingya Tewas, Rudenim Medan Overcapacity," http://news.okezone. com/read/2013/04/05/340/786683/8-pengungsi-rohingya-tewas-rudenim-medan-over-capacity, accessed 22 April 2015.

9 UNHCR (4), "All in the Same Boat: The Challenges of Mixed Migration," http://www.unhcr.org/ pages/4a1d406060.html, accessed 15 July 2015. 
of Economic and Social Affairs which notes that there are 213.943.812 international migrants worldwide. ${ }^{10}$ Basically, there are two forms of international migration: forced migration (especially refugee and asylum seeker movement but also that associated with disasters); and irregular migration. ${ }^{11}$ Systematically, the distinctions between asylum seeker, refugee and irregular migrant are:

Table 2: Definition of Asylum Seeker, Refugee, and Illegal Migrant ${ }^{12}$

$\begin{array}{ll} & \text { person (natural); } \\ \text { seeking to be accepted in a country as refugee; and } \\ \text { waiting for decision over their application for refugee status according to national and } \\ \text { international legal instrument. }\end{array}$

Two types of refugees are:

Refugee as a mandate person:

person (natural);

meet the criteria of refugee as stipulated by Statute of UNHCR; and

have the qualification to receive UN protection given by the High Commissioner, apart from whether he/she came from a State party to the 1951 Refugee Convention and its 1967 Protocol or whether he/she is recognized by resettlement country as a refugee

2. Refugee according to those instruments.

Refugee as a recognized person:

person (natural) due to his/her fear on the ground of fear of persecution because of race, religion, nationality, member of certain social or political group, being outside of his/her country of nationality and unable or because of his/her fear is unwilling to take the chance to get protection from aforementioned State; or

person (natural) due to being stateless and being outside of its former country of residence, impossible or, because of his/her fear, unwilling to return to his/her former residence.

a person who enters illegally or his/her visa is expired, he/she does not have a legal status either in the context of transit or settle in a resettlement country.

\section{Illegal migrant}

3. (sometimes referred to as "irregular migrant") terminology "irregular migrant" also applies to migrant who violates regulations with regards to permit of stay and to those who do not have the rights to stay in a resettlement country or can be referred to as illegal migrant, undocumented migrant, or migrant in irregular situation.

Basically, before their claims for refugee are approved, refugees were asylum seekers or individuals who have sought international protection and whose claims for refugee status are not yet determined, irrespective of when those claims may were lodged. ${ }^{13}$ The word "asylum" is the Latin counterpart of the Greek word "asylon," which means freedom from seizure. ${ }^{14}$ Historically, asylum has been regarded as a place of refuge where one could be free from the reach of a pursuer. ${ }^{15}$ In the ancient

10 UN Department of Economic and Social Affairs, Population Division, "Trends in International Migrant Stock: Migrants by Age and Sex,” http://esa.un.org/MigAge/p2k0data.asp,, accessed 25 July 2015.

11 Australia, Indonesia as a Transit Country in Irregular Migration to Australia (Australia: Australian Government Department of Immigration and Border Protection, 2014), p. 5.

12 This definition is derived from the Glossary on Migration published by the International Organization for Migration (IOM) in 2004 and freely translated by the Author.

${ }^{13}$ UNHCR (5), “UNHCR Population Statistics,” http://popstats.unhcr.org, accessed 15 July 2015.

14 Roman Boed, "The State of The Right of Asylum in International Law," Duke Journal of Comparative \& International Law Vol. 5 No. 1 (1994): 2.

15 Ibid. 
time, human sought shelter like cave or high places to take cover from weather, wild animals and/or other human. ${ }^{16}$ Along with the development of human's belief in the presence of Gods, human looked for shelter in sacred places from the pursuer either from religion authority or State authority. ${ }^{17}$ Emerging from human's belief to spiritual power and judiciary body thus the basis of asylum moved from sacred places to State or city sovereignty and asylum was then rendered by State for the sake of humanity. ${ }^{18}$

According to Global Facts and Figures published by UNHCR in 2012, the number of refugees in the beginning of 2013 worldwide reached 15.4 million refugees, and more than 893.700 people lodged asylum proposal in 2012, which is the second highest number in the last decade. ${ }^{19}$ Determination of refugee status can be carried out by State who is party to the 1951 Refugee Convention or administered by UNHCR in any non-party State. ${ }^{20}$ The main responsibility to identify people who fall under the category of refugee and to make sure that those people receive benefit from international protection and enjoy their rights and aid adhered to their refugee status is highly dependent on the State where applicant files an asylum. ${ }^{21}$ In practice, determination of refugee status is administered by UNHCR in the States which are not party to the 1951 Refugee Convention or in the States who are already party to the 1951 Refugee Convention but they have no mechanism or procedure for determining an asylum. ${ }^{22}$

Most forced migrants are not able to move directly to a place of permanent resettlement due to the largely unplanned and unanticipated nature of the move and the sudden circumstances which precipitate the move. ${ }^{23}$ For these reasons, the role of transit country in international migrations increases because this process can go on for a while and pass trough certain locations whether it is planned or not, before they can reach their final destination. One of the important transit points for most asylum seekers by sea, particularly for those trying to reach Australia, is Indonesia.

For Australia, Indonesia in many ways is an exemplary transit country in that it meets almost all of the defining characteristics of a transit country which include:

1. Its geographic location between the Middle East, Africa and Asia on the one hand, and Australia;

2. Its archipelago geography, comprising of more than 17.000 islands, presents virtually unlimited opportunities to enter Indonesia by boat without detection;

3. Its strong historical linkages, involving centuries of population movement and settlement, with the main origin countries in South Asia and the Middle East of many groups seeking to enter Australia and seek asylum;

4. Its complex contemporary migration system which not only involves important

16 S. Prakasih Sinha, Asylum and International Law (Den Haag: Martinus Nijhoff, 1971), p. 5. Asylum has been practiced for a long time, therefore scholars argue that "the practice of asylum is as old as humanity itself" (See Boed,loc.cit.).

17 Ibid., p. 275.

18 Ibid.

19 UNHCR (6), "Facts and Figures about Refugees," http://www.unhcr.org.uk/fileadmin/user_upload/ pdf/ Displacement_Facts_and_Figures_Final.pdf, accessed 15 July 2015.

20 Felicia Clarissa, "Tinjauan Hukum Internasional atas Search and Rescue terhadap Pencari Suaka yang Berada dalam Keadaan Bahaya di Laut," (Undergraduate Thesis Universitas Indonesia, Depok, 2014), p. 23.

${ }^{21}$ Ibid.

22 Ibid.

23 Australia, op.cit., p. 5. 
flows to the origins of asylum seekers and the other transit nations involved in their movement but has seen the development of a substantial migration industry;

5. A system of government in which corruption and briery play a significant role which opens up possibilities, not only for staying in Indonesia, but also in facilitating onward migration. ${ }^{24}$

Since Indonesia is not a party to the 1951 Refugee Convention and its 1967 Protocol, Indonesia does not render formal rights to asylum seekers and refugees within its territory. Indonesia merely provides "tolerance" for their presence under UNHCR or International Organization for Migration ("IOM"). Moreover, Indonesia does not have domestic mechanisms to process asylum claim or to give permanent protection and integration for asylum seekers. However, Indonesia is bound to the principle of non-refoulement (prohibition to return) contained in Article 33 of the 1951 Refugee Convention as a customary international law applicable to any refugee, asylum-seeker, or foreigner who needs some form of shelter from the State having control over them. ${ }^{25}$ This prohibition to return determines that:

"No Contracting State shall expel or return ("refouler") a refugee in any manner whatsoever to the frontiers of territories where his life or freedom would be threatened on account of his race, religion, nationality, membership of a particular social group or political opinion." 26

Pursuant to Article 42 paragraph (1) of the 1951 Refugee Convention, Article 33 of the 1951 Refugee Convention is one of the provisions which State may not make reservations. This nature is restated in Article VII paragraph (1) of the 1967 Protocol. Non-refoulement principle contained in Article 33 of the 1951 Refugee Convention also binds States which are not party to the 1951 Refugee Convention. ${ }^{27}$ Furthermore, UNHCR Executive Committee further stipulates that non-refoulement principle is an advancement of peremptory norm in international law or jus cogens which is a basic principle of international law accepted by States as non-derogable rights. ${ }^{28}$ However, non-refoulement principle may be exempted on two grounds: (i) in case an asylum seeker or refugee poses a threat to the national security of the host country; and (ii) in case their proven criminal nature and record may put the country in danger ${ }^{29}$ This principle is a reflection of commitment from international community to ensure the fulfillment of human rights, including individual rights to be free and feel safe or secure. ${ }^{30}$ Moreover, this principle can be understood as a prohibition to send asylum seeker or refugee to another State that may cause new persecution. ${ }^{31}$ At least nonrefoulement provides a temporary refuge to asylum seeker thus it can be interpreted

${ }^{24}$ Ibid., p. 6.

${ }^{25}$ Vladislava Stoyanova, "The Principle of Non-Refoulement and the Right of Asylum-Seekers to Enter State Territory," Interdisciplinary Journal of Human Rights Law Vol. 3 No. 1 (2008-2009): 1.

${ }^{26}$ UN General Assembly (1), Convention Relating to the Status of Refugees, 28 July 1951, United Nations Treaty Series Vol. 189.

27 Jovan Patrnogic, "Introduction to International Refugee Law," (Paper presented at Refugee Law Courses, the International Institute of Humanitarian Law, di San Remo, Italia, September 1996), p. 19.

${ }^{28}$ Jun Justinar, "Prinsip Non-Refoulement dan Penerapannya di Indonesia," http://pustakahpi. kemlu. go.id/app/Volume\%203,\%20September-Desember\%202011_18_23.PDF, accessed 15 July 2015, p. 20.

${ }^{29}$ UNHCR (7), "UNHCR Note on the Principle of Non-Refoulement," < http://www.refworld.org/docid/ 438c6d972.html>, accessed on 16 July 2015.

30 Clara Ignatia Tobing, "Penerapan Prinsip Non-Refoulement Dalam Kasus Relokasi Pencari Suaka Ilegal Australia Ke Pulau Manus dan Pulau Nauru," <http://pustaka.unpad.ac.id/wp-content/ uploads/2014/10/Penerapan-Prinsip-Non-refoulement.pdf>, accessed on 16 July 2015, p. 6.

31 Ibid. 
as partial or de facto asylum. ${ }^{32}$

Basically, protection for asylum seeker and refugee is the responsibility of every State whether it ratifies the 1951 Refugee Convention and its Protocol or not. The thing that differentiates between State party and non State party is the coverage of the rights and obligations between the two. Obviously, State party has broader rights and obligations than non State party. To the date, Indonesia views asylum seeker as illegal migrant due to the fact that most of them enter Indonesia's territory unlawfully by breaching Indonesia's immigration law with the absence of valid immigration document. This situation has lead to arrest and they end up in a detention center.

It is important to note that seeking asylum is not an unlawful act but detaining asylum-seekers for the sole reason of having entered without prior authorization runs counter to international law. ${ }^{33}$ Research shows that in $90 \%$ of cases, detained asylum seekers are eligible to be released from detention. ${ }^{34}$ The same research has showed that when asylum seeker is treated with respect and humane, they show higher rate of cooperation along the process till the end. ${ }^{35}$ Furthermore, there is proof supporting the relation between experiencing alternative detention before their asylum claim is rejected and an increase on the number of voluntary departure. ${ }^{36}$

In October 2012, UNHCR launched the new Guidelines on the Applicable Criteria and Standards relating to the Detention of Asylum-Seekers and Alternatives to Detention, replacing earlier Guidelines which were published in 1999. In the new Guidelines, UNHCR publishes special attachment on alternative detention, an additional part related to special or vulnerable group because of disability, age, gender, sexual orientation or gender identity, which requires special action, as well as recommendation to carry out independent surveillance and inspection in detention centers. For this reason, UNHCR collaborates with the Association for the Prevention of Torture and the International Detention Coalition to publish joint surveillance guidelines published in 2013. These guidelines also provide minimum procedural requirements and humane detention requirements. Therefore, in short, the legal issues on asylum seeker and refugee that will be addressed in this paper are:

\section{A. The Absence of Law}

According to current Indonesian law, refugee and asylum seeker who enters Indonesia's territory illegally is categorized as illegal migrant. It means that Indonesia has no mechanism which deals specifically with refugee and asylum seeker. Refugee and asylum seeker shall comply with Indonesia's immigration law and Regulation of the Directorate General of Immigration No. IMI-1489.UM.08.05 of 2010 on Handling Illegal Migrant ("Regulation of the Directorate General of Immigration on Handling Illegal Migrant"). According to Law 6/2011 and Regulation of the Directorate General of Immigration on Illegal Migrant, people who are put into detention center are:

1. Foreigner who is not victim of people smuggling or human trafficking which violates Indonesia's immigration law thus will be imposed with administrative

\footnotetext{
${ }^{32}$ Boed, Op. Cit., p. 16.

${ }^{33}$ UNHCR (8), Beyond Detention: A Global Strategy To Support Governments To End The Detention of Asylum-Seekers and Refugees, (Geneva: UNHCR, 2014), p. 5.

34 Alice Edwards, “Detention Under Scrutiny," Forced Migration Review, Vol. 44, (2013), p. 5.

${ }^{35}$ Ibid.

${ }^{36}$ Ibid.
} 
immigration action which is being put into detention center ${ }^{37}$;

2. Foreigner who is victim of people smuggling or human trafficking which violates Indonesia's immigration law thus will not be imposed with administrative immigration action but will still be put into detention center or other places ${ }^{38}$.

The logical consequences of these provisions are asylum seeker and refugee who are categorized as foreigner according to Indonesia's law and most of them enter Indonesia's territory by violating Indonesia's immigration law either as victim of people smuggling or human trafficking or none of those, will still be put into the detention center. According to a finding from National Commission of Human Rights, obscurity in the regulation on refugee and asylum seeker in Indonesia has lead to false treatment from Indonesian authority who categorizes them as illegal migrant due to incomplete immigration administrative, ${ }^{39}$ even though they have different background with other illegal migrant. ${ }^{40}$ Even if refugee status has been rendered by UNHCR, sometimes Indonesia will still refuse to release them from detention and will not acknowledge them as an individual who has the right to be in Indonesia's territory. ${ }^{41}$ Supposedly, for those "illegal migrants" who have obtained their refugee status, IOM will provide a living cost in the amount of 1.2 million Rupiah for each, while those who are not refugee will remain in detention center or deported to their home country. ${ }^{42}$ With the absence of law on the matter of asylum seeker and refugee, Indonesian Government will be more likely to violate human rights. ${ }^{43}$ Their rights are not guaranteed and they are prone to be a victim of human rights violation due to the fact that Indonesian law identifies them into the same category with illegal migrant because they reach Indonesia without prior authorization.

Intermingling between asylum seeker, refugee and illegal migrants into one place has resulted in many conflicts. A study by the Indonesia's Ministry of Human Rights in 2014 explains that conflict within detention center is divided into two: conflict among detained migrants and conflict between detained migrants and detention center officer. ${ }^{44}$ Factors that contribute to the conflict is varied such as lack of facility, inhumane treatment from detention center officer, political/ethnic group/religion/ race issues that were occurred in their home country, and stress resulting from the waiting process of their asylum claim to UNHCR. ${ }^{45}$ Consequently, a number of conflicts has occurred in Indonesia's detention center, namely:

${ }^{37}$ Indonesia (1), op.cit., art. 83.

38 Ibid., art. 86.

39 Purwanti K. dan Anita K., "Model Pembelajaran Bahasa," http://repository.uksw.edu/bitstream/ 123456789/3409/2/LAPPEN_\%20Purwanti\%20K,\%20Anita\%20K_\%20Model\%20Pembelajaran\%20 Bahasa_bab\%201.pdf, accessed 20 July 2015, p. 12.

${ }^{40}$ For instance, in January 2012, a group of Afghan refugees were caught and put in Bantul prison because they were going to traverse to Australia from Sentol beach in Bantul, Yogyakarta.

41 Human Rights Watch (1), "Indonesia: Anak-Anak yang Mencari Suaka Menemukan Kekerasan dan Penelantaran,” https://www.hrw.org/id/news/2013/06/23/250191, accessed 18 July 2015.

42 Berita Satu (1), "Kehidupan di Balik Rumah Detensi Imigrasi," http://www.beritasatu.com/ nasional/40170-kehidupan-di-balik-rumah-detensi-imigrasi.html, accessed 18 July 2015.

${ }^{43}$ LBH Jakarta (1), "Tetapkan Standar Prosedur Penanganan Pengungsi," http://www.bantuanhukum. or.id/web/blog/tetapkan-standar-prosedur-penanganan-pengungsi/, accessed 26 July 2015.

44 Abstracted from research finding of Badan Penelitian dan Pengembangan HAM Kementerian Hukum dan HAM, Implementasi Standar di Rumah Detensi Imigrasi dalam Upaya Pencegahan Konflik Antar Deteni.

45 Ibid. 
1. Persecution towards an illegal migrant in Pontianak detention center in the year of 2012 has caused him to die ${ }^{46}$;

2. Alleged sexual harassment towards three Rohingya refugees by Myanmar ship crews who were arrested for illegal fishing case in 2013 in Medan Detention Center, which may be caused by the absence of room separation based on gender within the detention center ${ }^{47}$;

3. Asylum seeker and refugee are not feeling comfortable in Medan Detention Center due to its lack of building facility where it is prone to flood. ${ }^{48}$

These conflicts illustrate that the absence of law is the root cause of inadequate protection and fulfillment of human rights for asylum seeker and refugee.

\section{B. Lack of Capacity and Facility}

Currently, Indonesia has 13 detention centers across the Indonesia's vast archipelago ${ }^{49}$ to accommodate those who are considered as illegal migrant according to Indonesia's immigration law. This number is inadequate considering that thousands of asylum seekers and/or refugees have illegally entered Indonesia. For instance, detention center in Kupang can only accommodate up to 90 people but currently it holds about 200 people..$^{50}$ Over-capacity has caused this detention center to take alternative steps such as moving some asylum seekers to another detention center which is still able to accept. This situation also occurs in detention center in Manado where it transfers approximately 20 out of 109 asylum seekers to the detention center in Surabaya. ${ }^{51}$ Sometimes, the detention center that receives transfer of asylum seekers also experiences over-capacity. The most notable example is in Balikpapan where it accepted 12 asylum seekers from Iran who were relocated from Makassar due to over-capacity ${ }^{52}$ despite the fact that the capacity of the detention center in Balikpapan can only accommodate 144 residents and currently it has reached 310 people. $^{53}$

Due to limitation in number of detention center and its capacity, the Indonesian government is forced to move some asylum seekers from detention center to a regular house, for instance in Jakarta's detention center some asylum seekers were relocated to a house in the city of Bogor. ${ }^{54}$ In other detention centers, asylum seekers or refugees

46 Tribun News, "PBB Bereaksi atas Penyiksaan Imigran di Pontianak," http://www.tribunnews.com/ regional/2012/03/03/pbb-bereaksi-atas-penyiksaan-imigran-di-pontianak, accessed 30 July 2015.

${ }^{47}$ Merdeka, "Peristiwa Kerusuhan di Rudenim Medan Dipicu Pelecahan Seksual," http://www.merdeka.com/peristiwa/kerusuhan-di-rudenim-medan-dipicu-pelecehan-seksual.html, accessed 30 July 2015.

48 Detik News, "Kisah Pencari Suaka Somalia di Medan," http://news.detik.com/bbc/2771260/kisahpencari-suaka-somalia-di-medan, accessed 30 July 2015.

49 "Dampak Singgahnya Pencari Suaka Ke Australia Terhadap Peningkatan Kejahatan Transnasional di Indonesia," http://journal.unair.ac.id/filerPDF/jahi0eaa661d8a2full.pdf, accessed 19 July 2015, p. 2. Indonesia's detention houses are located in Tanjung Pinang, Balikpapan, Denpasar, Jakarta, Kupang, Makassar, Manado, Medan, Pekanbaru, Pontianak, Semarang, Surabaya, and Jayapura.

${ }^{50}$ Kalimantan News, "Rudenim Kupang Tampung Imigran Lebihi Kapasitas," http://www.kalimantannews.com/berita.php?idb=30146, accessed on 20 July 2015.

51 Rimanews, “Over Kapasitas, Rudenim Manado Terbangkan Puluhan WNA ke Surabaya," http://nasional.rimanews.com/peristiwa/read/20140927/175010/Over-Kapasitas-Rudenim-Manado-Terbangkan-Puluhan-WNA-ke-Surabaya, accessed 20 July 2015.

${ }^{52}$ Kaltimpost, "Rudenim Makin Sesak," http://www.kaltimpost.co.id/berita/detail/219205-rudenimmakin-sesak.html, accessed 20 July 2015.

53 Ibid.

54 Antara News (1), "Jumlah Rudenim di Indonesia Masih Mencukupi," http://makassar. antaranews. com/berita/25380/jumlah-rudenim-di-indonesia-masih-mencukupi, accessed 18 July 2015. 
are put into a hotel due to limited capacity of the center. ${ }^{55}$ However, in other regions like Mataram, immigration officer has a hard time accommodating asylum seekers because there is currently no detention center in his region while local hotels are not willing to accept asylum seekers because of their bad behavior has once ruined some of hotel facilities and caused disturbance to other hotel guests. ${ }^{56}$

Over-capacity is allegedly to be the reason why many migrants are not content by staying in detention center and would rather run away from the center which often leads to fatalities because they got away by sea without adequate supplies. ${ }^{57}$ Besides, the number of officers in charge of security within one detention center is not sufficient compared to the number of migrants. Therefore it opens up the possibility of migrants fleeing from the center. For example, in 30 June 2009, there were 37 asylum seekers from Afghanistan successfully escaped from detention center in Pekanbaru by climbing the wall. ${ }^{58}$ This incident may be caused by the lack of officers doing night guards at that time, the absence of surveillance camera within the detention center, and over-capacity. ${ }^{59}$ Nevertheless, in some other detention centers which are equipped with surveillance camera such as in Kupang, this problem is still happening because of shortage in the number of officers doing night guards. ${ }^{60}$

Those conditions may happen because Indonesia is not a party to the 1951 Refugee Convention and its Protocol which causes determination of refugee status is highly dependent on UNHCR as the UN agency responsible for handling refugee matters. This dependency has lead to a long-drawn process that keeps refugees to remain in detention center for a lengthy period. ${ }^{61}$

\section{Indication of Violence and Negligence}

According to a report of Human Rights Watch on 23 June 2013, Indonesia is allegedly doing violence and negligence towards child migrant and asylum seeker. In this report, Human Rights Watch claims to have interviewer 102 migrants, age 5 to $66 .{ }^{62}$ Those migrants told that security officer in Indonesia's detention center take on some violence actions like kicking, punching, and slapping migrants. Some even

55 It happened in Kupang's detention house, where 200 asylum seekers had to relocate to Hotel Ina Boy while 200 more asylum seekers remained in the detention house (Okezone, "Petugas Kewalahan Awasi Pencari Suaka di Kupang," http://news.okezone.com/read/2015/06/11/340/1163760/petugas-kewalahan-awasi-pencari-suaka-di-kupang, accessed 19 July 2015). Moreover, around 96 Rohingyan refugees and Bangladesh migrants were temporarily moved from a refuge in Langkat to Wisma Keluarga (literally translated as "Family Home") in Medan before being placed in Hotel Beras Pati in Medan (Indopos, "96 Imigran Gelap Dari Bangladesh dan Myanmar Akan Dipindahkan ," http://www.indopos.co.id/2015/05/96imigran-gelap-dari-bangladesh-dan-myanmar-akan-dipindahkan.html, accessed 19 July 2015).

56 Berita Satu (2), "Imigrasi Mataram Kesulitan Tampung Imigran Suaka," http://sp.beritasatu.com/ home/ imigrasi-mataram-kesulitan-tampung-imirgan-suaka/27261, accessed 19 July 2015.

57 Hukum Online (2), “Beberapa Rumah Detensi Imigrasi Over Kapasitas,” http://www.hukum online. com/berita/baca/lt4faa63838ae24/beberapa-rumah-detensi-imigrasi-over-kapasitas, accessed 21 July 2015.

58 "Dampak Singgahnya Pencari Suaka Ke Australia Terhadap Peningkatan Kejahatan Transnasional di Indonesia," http://journal.unair.ac.id/filerPDF/jahi0eaa661d8a2full.pdf, accessed on 19 July 2015, p. 26.

${ }^{59}$ Ibid.

60 Antara News (2), "Imigran Gelap Kabur Dari Rudenim Kupang," http://www.antaranews.com/ berita/216061/44-imigran-gelap-kabur-dari-rudenim-kupang, accessed 20 July 2015. In Kupang's detention house, there are only four officers in charge for over 200 migrants.

${ }^{61}$ Hukum Online (2), loc.cit.

${ }^{62}$ Human Rights Watch (1), loc.cit. 
reported that they were tied, hit with a stick, burned with cigarette, and stung with electricity. ${ }^{63}$

\section{III.Indonesia's Role as a Transit Country}

In the past, as a transit country, Indonesia had used Galang Island and Lombok Island in detaining asylum seekers. Island as a detention center for asylum seeker and refugee is comparable to a "prison" because an island is basically a land surrounded by water thus it is almost impossible for asylum seeker and refugee to escape. These days, island detention facilities have been considered as a symbol of the suffering of asylum seekers deprived of many of their basic needs. ${ }^{64}$ Some of notorious island detention facilities are Lampedusa (Italy), Guam (United States), Australia, Manus Island (Papua New Guinea), and Nauru. ${ }^{65}$

In 1975, thousands of Vietnamese, and later, Cambodian, asylum seekers fled by boat to Indonesia and its neighboring countries. ${ }^{66}$ By 30 June 1979, the UN General Assembly reported that almost 43.000 Vietnamese and Cambodian boat people were present all over Indonesia. ${ }^{67}$ At that time, none of Southeast Asia countries had acceded to the 1951 Refugee Convention and its 1967 Protocol, not even a domestic mechanism to receive asylum seekers. With no screening mechanisms for asylum seekers in place yet, UNHCR granted all asylum seekers automatically prima facie refugee status and protection en bloc. ${ }^{68}$

Due to the massive scale of the exodus, the Southeast Asian countries appealed to the international community for burden sharing and assistance in managing the refugee flows ${ }^{69}$ Afterwards, the governments of Indonesia and the Philippines each offered to allocate one of their islands to set up regional processing centers. While the Philippines offered to host 7.000 refugees temporarily on Tara Island, the Indonesian government chose Galang Island as a temporary home for up to 10.000 refugees. $^{70}$ In this regard, Indonesian government stated that:

"that it would not receive refugees in its territory, but for the sake of humanitarianism it was forced to accept them during transit while they were waiting to move on to a third country, as well as actively providing thoughts and concrete support to find a solution for this problem." ${ }^{\prime 1}$

The meeting of ASEAN Foreign Ministers in May 1979 issued a statement on refugees, which stipulated that "countries providing the site or island for the

63 Ibid.

${ }^{64}$ Antje Missbach, "Waiting on the Islands of 'Stuckedness'. Managing Asylum Seekers in Island Detention Camps in Indonesia: From the Late 1970s to the Early 2000s," ASEAS - Austrian Journal of South-East Asian Studies Vol. 6 (2) (2013): 283.

65 Ibid.

66 Ibid:: 284. On 19 May 1975, 92 Vietnamese refugees passed through the town of Tarempa (Riau islands) on their way to Singapore. A week after that, a Vietnamese vessel landed in Laut Island (Riau islands). From then on, Vietnamese refugees started arriving almost on a daily basis at different islands in Riau archipelago, such as Batam, Bintan, Natuna, Anambas, and Kuku.

${ }^{67}$ Ibid.: 287.

${ }^{68}$ Ibid. UNHCR had to cover all costs approximately USD 18.562 .000 over a period of two years to establish and run the center in Galang island.

${ }^{69}$ Ibid.: 288.

${ }^{70}$ Ibid. Galang Island was chosen not only because of its strategic location and easily accessible by air and sea, it was also inhabited by only about 200 people.

${ }^{71}$ Ibid.: 288. 
processing center shall retain the sovereignty, administrative control and security responsibility over the island". ${ }^{72}$ All costs of establishing and running these centers were covered by the UNHCR. ${ }^{73}$ At the time, international community donated financial aid in total of USD 160 million to UNHCR to run these centers. ${ }^{74}$ It was envisioned that those refugees would stay only for a reasonable period, estimated around three to five years. ${ }^{75}$

Although an island can be utilized as an alternative detention center to a conventional detention center in the past, it only offers a temporary and short term solution but it does not solve the root causes of refugees and asylum seekers' problems in Indonesia. Therefore, if the Indonesian government aims to provide a long term solution on this issue, another alternative solution is required. However, does Indonesia accede to the 1951 Refugee Convention will solve this issue?

First of all, Indonesia has recognized international legal instruments such as Universal Declaration of Human Rights and ratified other international human rights treaties such as International Convention on Civil and Political Rights and Convention on the Rights of Child, thus Indonesia's obligation is to fulfill what is laid down in those human rights instruments. In the context of asylum seeker and refugee, Indonesia shall fulfill and protect the rights of asylum seekers and refugees in general for the sake of humanity.

Bearing in mind that the reason behind the establishment of Indonesian government is to get Indonesia involved in creating world peace through international relations carried out by the government, therefore in protecting the rights of those asylum seekers and refugees, Indonesia leastwise guarantees their human rights. Their most essential right is the rights to safety which one of them includes right to be free from torture or inhumane treatment. This right is guaranteed in the Article 28G paragraph (2) of the 1945 Constitution that states: ${ }^{76}$

"Every person shall have the right to be free from torture or inhumane and degrading treatment, and shall have the right to obtain political asylum from another country."

Since the subject of the Article 28G Paragraph (2) of the 1945 Constitution is "every person", then this "every person" may include asylum seekers and refugees who are in the Indonesia's territory. Their right to be free from torture or inhumane and degrading treatment shall be guaranteed. The protection toward this right does not mean diminishing the role of Indonesian government to enforce national law to asylum seekers and refugees, but more on the humanity sense from Indonesian government to them.

Rights to safety which are related to asylum seekers and refugees according to international human rights law instruments are:

1. Right to be free from torture, punishment or negligence;

2. Right to not to be arrested, imprisoned, tortured, alienated, or exiled in authorized manners; and

72 Ibid.

73 Ibid.

${ }^{74}$ Ibid:: 288 - 289.

75 Ibid:: 289. Both Tara Island and Galang Island merely served as a temporary refuge where refugees prepared for their resettlement such as by undertaking language and other courses. Despite initial plans to host them only temporarily, it was not until 1996 that the last Vietnamese left the camp on Galang Island.

${ }^{76}$ Indonesia (4), Op.cit., Article 28G Paragraph (2). 
3. Right to be recognized before the law.

Specifically, rights to safety which are related to asylum seekers and refugees based on national human rights law instruments are as follows:

1. Right to feel secure and peace;

2. Right to be free from torture, punishment or negligence;

3. Right to live in the society with peace, secure, and calm.

Therefore, in the context of asylum seekers and refugees, Indonesia's roles as a transit country as well as a non-party to the 1951 Refugee Convention related to right to safety are:

1. Since asylum seekers and refugees who unlawfully enter Indonesia's territory, pursuant to Indonesian law, are deemed as illegal migrant and therefore will be placed in a detention center, it is pivotal for Indonesia through its officers in its respective detention center to pay a close attention to human rights value and not conducting tortures or other forms of ill treatments to asylum seekers and refugees;

2. Asylum seekers and refugees are recognized before the law, in a sense, the recognition of their very existence as part of human being with needs, interests, and opinion;

3. In order to live in a peaceful society, asylum seekers and refugees together with society are at least given an understanding toward the issue in order to prevent conflicts among them.

Since Indonesia has limited resources, either funding, facilities, and official capacities, to handle asylum seekers and refugees, fulfillment and protection of right to safety can be carried out by Indonesia through collaboration with existing international organizations that are responsible for handling matters related to asylum seeker and refugee namely UNHCR and IOM. For example, IOM Indonesia established a non-detention house to accommodate asylum seekers and refugees who are deemed as vulnerable groups which in this case are women and children. ${ }^{77}$ Management of refugees can be executed by providing assistance in form of shelters, food and services facilities, or even by offering relief as a means to achieve firm status for each refugee. ${ }^{78}$

Even though there are limited numbers of detention center in Indonesia, there have been 42 accommodation facilities outside the detention center which belong to IOM and are located in 6 Indonesian cities, namely Medan, Batam, Jakarta, Yogyakarta, Surabaya, and Makassar. ${ }^{79}$ Until the end of August 2014, 2.599 migrants are under IOM supervision and sheltered in those facilities. ${ }^{80}$ The types of those facilities vary from low-budget housing to hotel but all of them were designed as integrated housing that have facilities and equipments to support a proper standard of living. ${ }^{81}$ Other than that, IOM also provides non-formal educational programs for those asylum seekers and refugees. ${ }^{82}$

${ }^{77}$ IOM (1), "Akomodasi Non Detensi IOM Indonesia," IOM Indonesia Newsletter Issue 4 (2014), http:// www.iom.or.id/sites/default/files/News-September-IND-zpo7_0.pdf, accessed 19 July 2015

78 Vera Puspita Ningsih,"Upaya Internasional Organization for Migration Dalam Menangani Masalah Imigran Gelap di Indonesia," eJournal Ilmu Hubungan Internasional Vol. 2 No. 2 (2014): 488.

${ }^{79} \operatorname{IOM}(1)$, loc.ct

80 Ibid.

${ }^{81} \mathrm{Ibid}$

${ }^{82}$ Ibid. 
Furthermore, it is important to note that even though Indonesia is a non-party to the 1951 Refugee Convention and its 1967 Protocol, Indonesia is a party to the Convention against Torture and Other Cruel, Inhuman or Degrading Treatment or Punishment ("Convention against Torture") that also prohibits refoulement in its Article 3 Paragraph (1). ${ }^{83}$ The difference between the term non-refoulement in those conventions is category of who may be protected from refoulement. The 1951 Refugee Convention only protects those who hold refugee status, whereas Convention against Torture widens its scope of protection to all people who are being targeted from violence actions. Although non-refoulement principle gives the obligation to not return the asylum seekers to a place where he or she can be persecuted, this principle does not give the obligation to grant asylum or to send him/her to other places.

In dealing with asylum seekers and refugees, Indonesia itself adheres to the principle of promoting durable solution with three (3) approaches:

i. Voluntary Repatriation or repatriation to their country of origin voluntarily; 84

ii. Resettlement in Third Country or placement in a third country;

iii. Local Settlement or placement in Indonesia, where the Indonesian government issues a temporary residence permit for refugees which will be reviewed when it expires $^{85}$

Local settlement became a final resort due to Indonesia's limited economic capacity and limited capacity in Indonesia's detention centers, while resettlement in a third country takes a relatively long time.$^{86}$ As a transit country for asylum seekers and refugees, the main problem faced by Indonesia is the absence of domestic system in managing asylum seeker and refugee because Indonesia is not a party to the 1951 Refugee Convention and its 1967 Protocol. The role of international organizations such as UNHCR and NGOs like IOM therefore becomes pivotal. In 2014, some 568 migrants had been repatriated to their home country by the help of Voluntary Repatriation Program, whereas 848 migrants holding refugee status have been resettled in a third country with the help from IOM. ${ }^{87}$

Since Indonesia is not a party to the 1951 Refugee Convention and its 1967 Protocol, then the determination of refugee status of an asylum seeker relies heavily on UNHCR as the UN agency in charge of refugee issues. The determination of the status of immigrants often takes a long time therefore they have to stay longer in

${ }^{83}$ United Nations, Convention against Torture and Other Cruel, Inhuman or Degrading Treatment or Punishment, 10 December 1984, U.N. Doc. A/39/51 (1984).

${ }^{84}$ Voluntary Repatriation be the main solution to the repatriation of several categories:

i. If the immigration authorities to facilitate the repatriation of immigrants have immigration documents and costs to return to their home country;

ii. The immigration authorities directly contact and coordinate with the embassies of the countries of origin of immigrants when immigrants have a fee, but do not have immigration documents;

iii. If the immigrant does not have immigration documents, do not have a cost for the home, the IOM will finance, manage documents to embassies.

85 Orpa Floria Sari, “Tanggung Jawab Indonesia Sebagai Negara Transit Terhadap Warga Negara Asing (WNA) Yang Terlibat Dalam Penyelundupan Manusia," http://download.portalgaruda.org/article.php? ar ticle $=188436 \& \mathrm{val}=6466 \&$ title=TANGGUNG\%20JAWAB $\% 20$ INDONESIA $\% 20$ SEBAGAI $\% 20$ NEGARA $\% 20$ TRANSIT\%20TERHADAP\%20WARGA\%20NEGARA\%20ASING\%20(WNA)\%20YANG\%20TERLIBAT\%20 DALAM\%20\%20PENYELUNDUPAN\%20MANUSIA\%20(Studi \%20 di\%20 Kantor\%20Imigrasi\%20 Kelas\%20II\%20Blitar), accessed 18 July 2015, p. 12.

${ }^{86}$ Ibid.

${ }^{87}$ IOM (2), "Imigrasi dan Manajemen Perbatasan," http://www.iom.or.id/sites/default/files/Factsheet \%20-\%20IBM\%20-\%20IND.pdf, accessed 18 July 2015. 
the detention center ${ }^{88}$ During the waiting period before being granted refugee status, there are indications of human rights violations such as ill-treatment, including physical attacks and detention in a long period of time and harsh interrogation procedures. ${ }^{89}$ Therefore, the Chairman of the National Commission on Human Rights, Ifdhal Kasim, reckons that it is better for Indonesia to immediately "annex" the 1951 Refugee Convention and its 1967 Protocol. According to Kasim, there are at least two benefits if Indonesia were to become a party to the 1951 Refugee Convention and its 1967 Protocol:

1. Indonesian Government may determine for themselves the status of refugees and asylum seekers so that the government can be directly involved and contribute to managing refugee problems in accordance with Indonesia's national interest;

2. Indonesian Government may acquire assistance and international cooperation to strengthen its national capacity in dealing with asylum seekers and refugees, therefore a more comprehensive solution in handling asylum seekers and refugees is expected. Those asylum seekers and refugees who are not fully covered by the government can be subsidized through international cooperation fund. ${ }^{90}$

Basically, the House of Representatives ("DPR") Indonesia supports the ratification of the 1951 Refugee Convention and its 1967 Protocol, but the process of ratification of an international treaty puts Parliament as a passive party in the sense that Parliament merely waits for submission from the Executive. ${ }^{91}$ In the RANHAM for period of 2004-2009 and 2010-2014, Indonesian government has actually showed a positive response to accede the 1951 Refugee Convention and its 1967 Protocol, but the current conditions in Indonesia where it is still susceptible or incapable of doing so does not allow it to be done. ${ }^{92}$ Factors preventing the Indonesian government to accede to the 1951 Refugee Convention and its 1967 Protocol are divided in two respects:

\section{External Factors}

a. Several provisions in the 1951 Refugee Convention are considered as burdensome and hard to attain by Indonesia, ${ }^{93}$ such as:

1) The provisions of Article 13, Article 14 and Article 30 of the 1951 Refugee Convention obliges State parties to assist or facilitate the transfer of property and assets of refugee to a country where he/she will be resettled;

2) The provisions of Article 17, Article 18, and Article 19 provide freedom to refugees to obtain employment that generate wage, to do their own business such as agriculture and to establish a company. Meanwhile Indonesia itself still struggles to ensure that its citizen have a decent job;

3) The fulfillment of the right to education under Article 22 also brings up a dilemma for the government because there are many Indonesian citizens who are still unable to access education;

\footnotetext{
${ }^{88}$ Hukum Online (2), loc.cit.

${ }^{89}$ Afriandi, op.cit., p. 4.

${ }^{90}$ Hukum Online (2), loc.cit.

91 Ria Rosianna Simbolon, "Penundaan Ratifikasi Konvensi 1951 dan Protokol 1967 tentang Status Pengungsi Oleh Pemerintah Indonesia," eJournal Ilmu Hubungan Internasional Vol. 2 No.2 (2014): 454.

${ }_{92}$ Ibid.

93 Ibid.: 455 .
} 
4) Article 21 and Article 24 are also hard to meet due to the fact that this provision grants the right to welfare for refugees such as in the form of housing and allowances;

b. By acceding to the 1951 Refugee Convention and its 1967 Protocol, the mandate to grant a refugee status and its determination process that originally belong to the UNHCR will be transferred to the Indonesian government, including the obligation to satisfy the needs of refugees and asylum seekers in Indonesia. Therefore the government shall create a special budget to ensure the fulfillment of the rights of refugees in conformity with the Convention ${ }^{94}$;

c. Indonesia concerns that by acceding to the 1951 Refugee Convention and its 1967 Protocol, the number of refugees will increase and so will international crime that may put the security and stability of Indonesia in peril ${ }^{95}$

\section{Internal factors}

a. If Indonesia decides to accede to the 1951 Refugee Convention and its 1967 Protocol, the Government should enhance the quality of Indonesia's law enforcers, particularly at the borders;

b. Accession to the 1951 Refugee Convention and its 1967 Protocol will certainly have an impact on Indonesia's economy, especially with regards to the cost of handling asylum seekers and refugees that will be borne by the government which are:

1) Cost to train institution and its personnel involved in handling refugees;

2) Cost to determine refugee status, such as the cost for professional personnel for registration and interviews, cost for interpreter, as well as the cost for providing basic needs of asylum-seekers during the process;

3) The cost of resettlement or placement in a safe third country;

c. In case of local integration, if refugees and local community cannot live side by side, it may cause conflicts and new problems for Indonesia. Refugees who come from varied cultural backgrounds are not always in harmony with the cultural values of local community. ${ }^{96}$

On the other hand, Australian government has stated that starting from July 2015 asylum seekers who are registered with UNHCR Jakarta are not allowed to stay in Australia. However, Australia will still process those refugees who were registered before July 2014 but with fewer resettlement quotas, ${ }^{97}$ from 600 people to 450 people per year. ${ }^{98}$ According to the Australian Immigration Minister, Scott Morrison,

94 Ibid::456. Although in this case, according to Enny Soeprapto, Indonesia does not have to worry about the cost, as this will be borne together with the international community and will be assisted by UNHCR (More on Kompas, "Indonesia Need Ratification Convention on Refugees," http: //perpustakaan. bappenas.go.id/lontar/file?file=digital/ BLOB / F919 / Indonesia\% 20Perlu\% 20Ratifikasi.htm, accessed 3August 2015).

95 Ibid.: 457.

96 Ibid:: 458

${ }^{97}$ BBC, “Indonesia 'terbebani' Sikap Australia Yang Menolak Pencari Suaka," http://www.bbc.com/ indonesia/berita_indonesia/2014/11/141119_indonesia_pencarisuaka_australia, accessed on 18 July 2015.

98 LBH Jakarta (2), "Anti Resettlement Policy Australia Increasingly Make It Is Difficult for The Transit Refugees in Indonesia," http://www.bantuanhukum.or.id/web/blog/kebijakan-anti-resettlementaustralia-semakin-mempersulit-pengungsi-yang-transit-di-indonesia/, accessed 26 July 2015. The quota 
this policy is made to stop the notion that refugees may go to Indonesia to use it as a transit country before reaching Australia. ${ }^{99}$ This Australia's policy is deemed as in contrary to Australia's obligations as a State party to the 1951 Refugee Convention and it will create an uncertainty to those refugee and asylum seekers in Indonesia which currently reaches about 4.300 refugees and 6.200 asylum seekers. ${ }^{100}$ The fact that Australia issues quota restrictions does not rule out the possibility that if Indonesia accedes to the 1951 Refugee Convention and its 1967 Protocol, the former status of Indonesia as a transit country will transform into a major destination country for asylum seekers.

Thus, the urge to accede to the 1951 Refugee Convention and its 1967 Protocol should also include a careful consideration on Indonesia's ability, notably its financial capacity and its main load to provide welfare for its citizens. In considering whether or not Indonesia should accede to the 1951 Refugee Convention and its 1967 Protocol, social aspects related to the process of assimilation between local Indonesians and the new arrivals who come from different cultural background should be taken into account because it is prone to conflict that may pose a threat to the security of the country. ${ }^{101}$ In addition, treatments and facilities that are provided for refugee can potentially cause "social jealousy" for many Indonesians living under poverty.

\section{Conclusion}

The legal issues of asylum seekers and refugees in Indonesia comprise the absence of legal protection that deal specifically with refugees and asylum seekers which under Indonesian law they may be classified as illegal migrants and they may be subject to administrative action and being put in detention center. Second of all, there are capacity and facility in Indonesia's detention center affecting the fulfillment of the right to safety of asylum seekers and refugees, and lastly there are indications of abuse and negligence in Indonesia's detention center.

As a non State party to the 1951 Refugee Convention and its 1967 Protocol, Indonesia still accepts asylum seekers and refugees within certain time limits based on humanitarian grounds. Indonesia has tried to meet the basic rights of those refugees and asylum seekers, leastwise by ensuring the fulfillment of the right to safety. In this regard, Indonesia may cooperate with relevant international organizations such as UNHCR and NGOs like IOM to handle asylum seekers and refugees in Indonesia. In the end, this paper realizes the need for Indonesia to accede to the 1951 Refugee Convention and its 1967 Protocol, however considering various obstacles either externally and internally, it is indispensable for Indonesia to enhance its capacity before Indonesia expresses its consent to be bound to the 1951 Refugee Convention and its 1967 Protocol.

for resettlement to Australia is the largest compared to other countries such as New Zealand, the United States, Canada or Germany which together in total only receive below $10 \%$ of the total number of refugees received by Australia.

${ }^{99} \mathrm{BBC}$, loc.cit.

${ }^{100}$ LBH Jakarta (2), loc.cit.

101 For example, in late October 2012, the Immigration Office in Bogor responded to the ultimatum from a resident of Cisarua who wanted the region to be free from asylum seekers from the Middle East who roam in residential areas, especially in Puncak, Cisarua (More on "Impact haven asylum seekers to Australia Against Increased Crime transnational in Indonesia," http://journal.unair.ac.id/filerPDF/jahi0eaa661d8a2full.pdf, accessed 19 July 2015, p. 27). 
Finally, even though Indonesia may not accede to the 1951 Refugee Convention and its 1967 Protocol, Indonesia may establish domestic mechanism or procedure for law enforcer in dealing with asylum seekers and refugees in accordance with applicable international standards. Furthermore, Indonesia should be able to create a legal framework that clearly distinguishes between "illegal migrants" and "asylum seekers" or "refugees". It is also pivotal for Indonesia to encourage its detention center's officers to pay a close attention to human rights and to avoid any action that constitutes as violence or persecution towards asylum seekers and refugees.

\section{Bibliography}

\section{Legal Documents}

ASEAN. ASEAN Human Rights Declaration.

Indonesia. Immigration Directorate Rule on Handling Illegal Immigrants. Rule No. IMI1489.UM.08.05 Year 2010.

Indonesia. Peraturan Pemerintag tentang Pelaksanaan Undang-Undang No. 6 Thaun 2011 (Government Regulation regarding Implementing Regulations on Law No. 6 Year 2011). PP No. 31 of 2013 (Government Regulation No. 31 Year 2013).

Indonesia. Undang-Undang Dasar Negara Republik Indonesia Tahun 1945. The 1945 Constitution of the Republic of Indonesia.

Indonesia. Undang-Undang tentang Hak Asasi Manusia (Law regarding Human Rights). UU No. 39 Tahun 1999, LN No. 165 Tahun 1999 (Law No. 39 Year 1999, SG No. 165 Year 1999).

Indonesia. Undang-Undang tentang Keimigrasian (Law regarding Immigration). UU No. 6 Tahun 2011, LN No. 52 Tahun 2011 (Law No. 6 Year 2011, SG No. 52 Year 2011).

People Consultative Assembly of the Republic of Indonesia. Resolution of People Consultative Assembly of the Republic of Indonesia No. XVII/MPR/1998 on Human Rights.

UN General Assembly. Convention Relating to the Status of Refugees. 28 July 1951. United Nations Treaty Series Vol. 189.

UN General Assembly. Convention against Torture and Other Cruel, Inhuman or Degrading Treatment or Punishment. 10 December 1984, U.N. Doc. A/39/51 (1984)

UN General Assembly. Universal Declaration of Human Rights. 10 December 1948. 217 A (III).

UN General Assembly. International Covenant on Civil and Political Rights. 16 December 1966. United Nations, Treaty Series, vol. 999, p. 171.

United Nations. Charter of the United Nations. 24 October 1945. 1 UNTS XVI,

\section{Books}

Amnesty International. There Is A Way Out: Stop Abuse of Migrants Detained in Malaysia. London: Amnesty International, 2010.

Augusto, Antonio. Universal Declaration of Human Rights. New York: United Nations Audiovisual Library of International Law, 2008.

Australian. Indonesia as a Transit Country in Irregular Migration to Australia. Australia: Australian Government Department of Immigration and Border Protection, 2014. 
El-Muhtaj, Majda. Hak Asasi Manusia dalam Konstitusi Indonesia: Dari UUD 1945 sampai dengan Amandemen UUD 1945 Tahun 2002. Jakarta: Prenada Media, 2005.

Human Rights Commission of Malaysia. Roundtable on Alternatives to Immigration Detention. Kuala Lumpur: Human Rights Commission of Malaysia, 2013.

Kneebone, Susan. "ASEAN and the Conceptualization of Refugee Protection in Southeastern Asian States," dalam Ademola Abass dan Francesca Ippolito (ed), Regional Approaches to the Protection of Asylum Seekers: An International Legal Perspective. Surrey: Ashgate Publishing Limitate, 2014.

Sinha, S. Prakasih. Asylum and International Law. Den Haag: Martinus Nijhoff, 1971.

The Constitutional Court of the Republic of Indonesia. Naskah Komprehensif Perubahan Undang-Undang Dasar Negara Republik Indonesia Tahun 1945: Latar Belakang, Proses, dan Hasil Pembahasan 1999-2002 Buku II Sendi-Sendi/Fundamental Negara. Jakarta: Sekretariat Jenderal dan Kepaniteraan Mahkamah Konstitusi, 2010.

Tomuschat, Christian. International Covenant on Civil and Political Rights. New York: United Nations Audiovisual Library of International Law, 2008.

UNHCR. Beyond Detention: A Global Strategy to Support Governments To End The Detention of Asylum-Seekers and Refugees. Geneva: UNHCR, 2014.

\section{Articles}

Baets, Antoon De. "The Impact of the Universal Declaration of Human Rights on the Study of History." History and Theory Volume 48 Issue 1 (January 2009): 20-43.

Boed, Roman. "The State of The Right of Asylum in International Law." Duke Journal of Comparative \& International Law Vol. 5 No.1 (1994): 1-34.

Briskman, Linda, Lucy Fiske dan Michelle Dimasi. "The Impact of Australian Asylum Seeker Policy on Christmas Islanders (2001-2011)." Shima: The International Journal of Research Into Island Cultures Vol. 6 No. 2. (2012): 99-115.

Edwards, Alice. "Detention under Scrutiny." Forced Migration Review Vol. 44. (September 2013): 4-6.

Harendro, Dody. "Bali Process: Upaya Regional Mengatasi Kejahatan Lintas Batas." Diplomasi Multilateral Vol 2 No. 2 (2013): 15-19.

IOM. "Akomodasi Non Detensi IOM Indonesia." IOM Indonesia Newsletter Issue 4 (2014). http://www.iom.or.id/sites/default/files/News-September-INDzpo7 0.pdf. Accessed 19 July 2015.

Krustiyati, Atik. "Kebijakan Penanganan Pengungsi di Indonesia: Kajian dari Konvensi Pengungsi Tahun 1951 dan Protokol 1967". Law Review Vol. 12 (2) (2012).

Missbach, Antje. "Waiting on the Islands of 'Stuckedness'. Managing Asylum Seekers in Island Detention Camps in Indonesia: From the Late 1970s to the Early 2000s." ASEAS - Austrian Journal of South-East Asian Studies Vol. 6 (2). (2013): 281-306.

Muhamad, Simela Victor. "Masalah Pengungsi Rohingya, Indonesia, dan ASEAN." Info Singkat, Vol VII No. 10/P3DI/Mei 2015 (May 2015): 5-8.

Ningsih, Vera Puspita. "Upaya Internasional Organization for Migration Dalam Menangani Masalah Imigran Gelap di Indonesia." eJournal Ilmu Hubungan Internasional Vol. 2 (2) (2014): 477-490.

Riyanto, Sigit. "Urgensi Legislasi Hukum Pengungsi dan Kendalanya di Indonesia". Jurnal Hukum Internasional Vol. 2 No. 1 (Oktober 2004): 67-86.

Simbolon, Ria Rosianna. "Penundaan Ratifikasi Konvensi 1951 dan Protokol 1967 tentang Status Pengungsi Oleh Pemerintah Indonesia." eJournal Ilmu Hubungan 
Internasional Vol. 2(2) (2014): 450-460.

Stoyanova, Vladislava. "The Principle of Non-Refoulement and the Right of AsylumSeekers to Enter State Territory." Interdisciplinary Journal of Human Rights Law Vol. 3 (1). (2008-2009): 1-11.

\section{Websites}

Afriandi, Fadli. “Kepentingan Indonesia Belum Meratifikasi Konvesi 1951 dan Protokol 1967 Mengenai Pengungsi Internasional dan Pencari Suaka." http://download. portalgaruda.org/article.php?article $=185990 \& \mathrm{val}=6444 \&$ title $=$ KEPENTIN GAN\%20INDONESIA\% 20BELUM\%20MERATIFIKASI\%20KONVENSI\%20 1951\%20DAN\%20PROTOKOL\%201967\%20MENGENAI\%20PENGUNGSI\%20INTERNASIONAL\%20DAN\%20PENCARI\%20SUAKA. Accessed 3 August 2015.

Al Faruque, Abdullah. "Plight of Rohingya Refugees in Bangladesh: Legal Aspects of the Problem". http://www.culaw.ac.bd/files/plight of ruhingyas.pdf. Accessed 19 June 2015.

Antara News. "Imigran Gelap Kabur Dari Rudenim Kupang." http://www.antaranews. com/ berita/216061/44-imigran-gelap-kabur-dari-rudenim-kupang. Accessed 20 July 2015.

Antara News. "Jumlah Rudenim di Indonesia Masih Mencukupi." http://makassar. antaranews.com/berita/25380/jumlah-rudenim-di-indonesia-masihmencukupi. Accessed 18July 2015.

BBC. "Indonesia 'terbebani' Sikap Australia Yang Menolak Pencari Suaka." http:// www.bbc.com/indonesia/berita indonesia/2014/11/141119 indonesia pencarisuaka australia. Accessed 18 July 2015.

Berita Satu. "Imigrasi Mataram Kesulitan Tampung Imigran Suaka." http:// sp.beritasatu.com/home/ imigrasi-mataram-kesulitan-tampung-imirgansuaka/27261. Accessed 19 July 2015.

Berita Satu. "Kehidupan di Balik Rumah Detensi Imigrasi." http://www.beritasatu. com/ nasional/40170-kehidupan-di-balik-rumah-detensi-imigrasi.html. Accessed 18 July 2015.

Detik News. "Kisah Pencari Suaka Somalia di Medan." http://news.detik.com/ bbc/2771260/ kisah-pencari-suaka-somalia-di-medan. Accessed 30 July 2015.

Directorate on Immigration and Human Rights. "Imigrasi Nasional dan Problem Pencari Suaka." http://bpsdm.kemenkumham.go.id/artikel-bpsdm/130imigrasi-nasional-dan-problem-pencari-suaka. Accessed 22 April 2015.

Directorate on Immigration and Human Rights. "Beberapa Rumah Detensi Imigrasi Over Kapasitas". http://jakarta.kemenkumham.go.id/berita-hukum-danham/671-beberapa-rumah-detensi-imigrasi-over-kapasitas-. Accessed 22 April 2015.

Dompet Dhuafa. "Situation Report: Indonesia - Rohingya Refugees." http://reliefweb. int/sites/reliefweb.int/files/resources/Indonesia\%20Sitrep\%20DMC\%20 Dompet\%20Dhuafa\%20Rohingya\%20Refugees\%20as\%20of\%20\%208\%20 July\%202015.pdf. Accessed 3 August 2015.

Global Detention Project. "Malaysia Detention Profile." http://www. globaldetentionproject. org/countries/asia-pacific/malaysia/introduction. html. Accessed 31 Juli 2015.

Global Detention Project. "Migration-Related Detention and International Law." http://www.globaldetentionproject.org/law/legal-framework/international/ treaties-and-protocols.html. Accessed 17 June 2015. 
Hansard. http://www.aph.gov.au/hansard/senate/commttee/S10246.pdf. Accessed on the 8 July 2015.

Hukum Online. "Beberapa Rumah Detensi Imigrasi Over Kapasitas.” http://www. hukum online.com/berita/baca/lt4faa63838ae24/beberapa-rumah-detensiimigrasi-over-kapasitas. Accessed 21 July 2015.

Hukum Online. "Indonesia Perlu Ratifikasi Konvensi Tentang Pengungsi." http://www. hukumonline.com/berita/baca/lt4f351aacc4a70/indonesia-perlu-ratifikasikonvensi-tentang-pengungsi. Accessed 22 April 2015.

Human Rights Watch. "Indonesia: Anak-Anak Yang Mencari Suaka Menemukan Kekerasan dan Penelantaran." https://www.hrw.org/id/ news/2013/06/23/250191. Accessed 18 Juli 2015.

Human Rights Watch. "Malaysia: UN Review Should Challenge Rights Record: End Preventative Detention, Investigate Abuse." http://www.hrw.org/ news/2009/02/09/ malaysia-un-review-should-challenge-rights-record. Accessed 31 July 2015.

Indopos. "96 Imigran Gelap Dari Bangladesh dan Myanmar Akan Dipindahkan." http://www.indopos.co.id/2015/05/96-imigran-gelap-dari-bangladesh-danmyanmar-akan-dipindahkan.html. Accessed on the 19 July 2015.

IOM. "Imigrasi dan Manajemen Perbatasan," http://www.iom.or.id/sites/default/ files/ Factsheet\%20-\%20IBM\%20-\%20IND.pdf. Accessed 18 July 2015.

Justinar, Jun. “Prinsip Non-Refoulement dan Penerapannya di Indonesia." http:// pustakahpi. kemlu. go.id/app/Volume\%203,\%20September-Desember\%20 2011_18_23.PDF. Accessed 15 July 2015.

K., Purwanti dan Anita K. "Model Pembelajaran Bahasa." http://repository.uksw.edu/ bitstream/123456789/3409/2/LAPPEN_\%20Purwanti\%20K,\%20Anita\%20 K_\%20Model\%20Pembelajaran\%20Bahasa_bab\%201.pdf. Accessed 20 July 2015.

Kalimantan News. "Rudenim Kupang Tampung Imigran Lebihi Kapasitas." http:// www.kalimantan-news.com/berita.php?idb=30146. Accessed 20 July 2015.

Kaltimpost. "Rudenim Makin Sesak." http://www.kaltimpost.co.id/berita/ detail/219205-rudenim-makin-sesak.html. Accessed 20 July 2015.

Kompas. "Indonesia Perlu Ratifikasi Konvensi Tentang Pengungsi." http:// perpustakaan.bappenas.go.id/lontar/file?file=digital/blob/F919/ Indonesia\%20Perlu\%20Ratifikasi.htm. Accessed 3 August 2015.

LBH Jakarta. "Kebijakan Anti Resettlement Australia Semakin Mempersulit Pengungsi Yang Transit di Indonesia." http://www.bantuanhukum.or.id/web/blog/ kebijakan-antiresettlement-australia-semakin-mempersulit-pengungsi-yangtransit-di-indonesia/. Accessed on the 26 July 2015.

LBH Jakarta. "Tetapkan Standar Prosedur Penanganan Pengungsi." http://www. bantuanhukum.or.id/web/blog/tetapkan-standar-prosedur-penangananpengungsi/. Accessed 26 July 2015.

Merdeka. "Peristiwa Kerusuhan di Rudenim Medan Dipicu Pelecahan Seksual." http://www.merdeka.com/peristiwa/kerusuhan-di-rudenim-medan-dipicupelecehan-seksual.html. Accessed 30 July 2015.

Okezone. "Petugas Kewalahan Awasi Pencari Suaka di Kupang." http://news.okezone. com/read/2015/06/11/340/1163760/petugas-kewalahan-awasi-pencarisuaka-di-kupang. Accessed 19 July 2015.

Okezone. "Pengungsi Rohingya Tewas, Rudenim Medan Over Capacity." http://news. okezone.com/read/2013/04/05/340/786683/8-pengungsi-rohingya-tewasrudenim-medan-over-capacity. Accessed 22 April 2015. 
Rimanews. "Over Kapasitas, Rudenim Manado Terbangkan Puluhan WNAke Surabaya." http://nasional.rimanews.com/peristiwa/read/20140927/175010/OverKapasitas-Rudenim-Manado-Terbangkan-Puluhan-WNA-ke-Surabaya. Accessed 20 July 2015.

Sari, Orpa F. “Tanggung Jawab Indonesia Sebagai Negara Transit Terhadap Warga Negara Asing (WNA) Yang Terlibat Dalam Penyelundupan Manusia." http:// download. portalgaruda.org/article.php?article=188436\&val=6466\&title =TANGGUNG\%20JAWAB \%20INDONESIA\%20SEBAGAI\%20 NEGARA\%20 TRANSIT \% 20 T ERH ADAP \% 20 WARGA \% 20 NEGARA \% 20 AS IN G \% 20 (WNA)\%20YANG\%20TERLIBAT\%20DALAM\%20\%20PENYELUNDUPAN\%20 MANUSIA\%20(Studi\%20di\%20Kantor\%20Imigrasi\%20Kelas\%20II\%20 Blitar). Accessed 18 July 2015.

Tribun News. "PBB Bereaksi atas Penyiksaan Imigran di Pontianak." http://www. tribunnews.com/regional/2012/03/03/pbb-bereaksi-atas-penyiksaanimigran-di-pontianak. Accessed 30 July 2015.

Tobing, Clara Ignatia. "Penerapan Prinsip Non-Refoulement Dalam Kasus Relokasi Pencari Suaka Ilegal Australia Ke Pulau Manus dan Pulau Nauru." http:// pustaka.unpad.ac.id/wp-content/ uploads/2014/10/Penerapan-Prinsip-Nonrefoulement.pdf. Accessed 16 July 2015.

UN Department of Economic and Social Affairs, Population Division. "Trends in International Migrant Stock: Migrants by Age and Sex." http://esa.un.org/ MigAge/ p2k0data.asp. Accessed 25 July 2015.

UNHCR. "All in the Same Boat: The Challenges of Mixed Migration." http://www.unhcr. org/ pages/4a1d406060.html. Accessed 15 July 2015.

UNHCR. "Facts and Figures about Refugees." http://www.unhcr.org.uk/fileadmin/ user_upload/pdf/Displacement_Facts_and_Figures_Final.pdf. Accessed on the 15 July 2015.

UNHCR. "Living As Refugee in Malaysia." http://www.unhcr.org.my/refugeeMsia. htm\#. Accessed 31 July 2015.

UNHCR. "Pelatihan Keselamatan dan Keamanan di Rudenim Tanjung Pinang." http:// www.unhcr.or.id/id/pelatihan-keselamatan-dan-keamanan-di-rudenimtanjung-pinang. Accessed 22 April 2015.

UNHCR. "Protocol Relating to the Status of Refugees." http://www.ohchr.org/ Documents/ProfessionalInterest/protocolrefugees.pdf. Accessed 26 May 2015.

UNHCR. "Relasi dengan Pemerintah dan Peningkatan Kapasitas". http://www. unhcr.or.id/id/tugas-a-kegiatan/relasi-dengan-pemerintah-a-peningkatankapasitas. Accessed 22 April 2015.

UNHCR. "States Parties to the 1951 Convention relating to the Status of Refugees and the 1967 Protocol." http://www.unhcr.org/3b73b0d63.html. Accessed 19 June 2015.

UNHCR. "UNHCR di Indonesia". http://www.unhcr.or.id/id/unhcr-ambassador-id. Accessed 22 April 2015.

UNHCR. "UNHCR Note on the Principle of Non-Refoulement." http://www.refworld. org/ docid/ 438c6d972.html. Accessed 16 July 2015.

UNHCR. “UNHCR Population Statistics." http://popstats.unhcr.org/. Accessed 15 July 2015.

VOA Indonesia. "Warga Rohingya Hadapi Ketidakpastian di Indonesia." http:// www.voaindonesia.com/content/warga-rohingya-hadapi-ketidakpastian-diindonesia/1695594.html. Accessed 19 April 2015. 
"Dampak Singgahnya Pencari Suaka Ke Australia Terhadap Peningkatan Kejahatan Transnasional di Indonesia." http://journal.unair.ac.id/filerPDF/ jahi0eaa661d8a2full.pdf. Accessed 19 July 2015.

"The Italian Asylum System." http://www.resettlement-observatory.eu/ documents/italy/ outputs/countryprofile/italycountryprofile.pdf. Accessed on the 18 July 2015.

\section{Others}

Afriansi, Fadli. "Kepentingan Indonesia Belum Meratifikasi Konvensi 1951 dan Protokol 1967 Mengenai Pengungsi Internasional dan Pencari Suaka".

Australia, "Indonesia as a Transit Country in Irregular Migration to Australia," Irregular Migration Research Programme (2014).

Australian Human Rights Commission. "Asylum Seekers, Refugees and Human Rights." Snapshot Report (2013).

Bem, Kazimierz. Et.al. "A Price Too High: The Cost of Australia's Approach to Asylum Seekers." (2007).

Body for Human Rights Research and Development Ministry of Law and Human Rights. Implementasi Standar di Rumah Detensi Imigrasi dalam Upaya Pencegahan Konflik Antar Deteni.

Brett, Margaret Edith. "The Right to Recognition as a Person before the Law and the Capacity to Act under International Human Rights Law." (LL.M in International Human Rights Law National University of Ireland, Galway, 2012).

Clarissa, Felicia. "Tinjauan Hukum Internasional Atas Search and Rescue Terhadap Pencari Suaka Yang Berada Dalam Keadaan Bahaya di Laut." (Undergraduate thesis Universitas Indonesia, Depok, 2014).

Dewi, Sisilia Nurmala. "Efektivitas Hukum terkait Jaminan Hak atas Kebebasan Beragama di Indonesia Periode 2005-2011 (Studi Kasus: Jemaat Ahmadiyah Indonesia)." (Undergraduate thesis Universitas Indonesia Depok, 2012).

International Federation for Human Rights. "Undocumented migrants and refugees in Malaysia: Raids, Detention, and Discrimination." Suara Rakyat Malaysia. (March 2008).

Jayadi, Anbar. "Hak Atas Kebebasan Beragama dan Berkeyakinan di Indonesia Dalam Perspektif Hukum Asasi Manusia Internasional." (Undergraduate thesis Universitas Indonesia, Depok, 2015).

Krustiyati, Atik. "Aspek Hukum Internasional Penyelesaian Pengungsi Timor Leste". (Dissertation Postgraduate Program Universitas 17 Agustus 1945, 2009).

Patrnogic, Jovan. "Introduction to International Refugee Law." (Papear presented at Refugee Law Courses, the International Institute of Humanitarian Law, di San Remo, Italia September 1996).

Refugees International. “Rohingya: Burma's Forgotten Minority”. Field Report (19 December 2008).

UNHCR. CCPR General Comment No. 16: Article 17 (Right to Privacy), 8 April 1988. Office of the High Commissioner for Human Rights.

UNHCR. CCPR General Comment No. 20: Article 7 (Prohibition of Torture, or Other Cruel, Inhuman or Degrading Treatment or Punishment), 10 March 1992. Office of the High Commissioner for Human Rights.

UNHCR. CCPR General Comment No. 27: Article 12 (Freedom of Movement), 2 November 1999, CCPR/C/21/Rev.1/Add.9. Office of the High Commissioner for Human Rights. 